Journal of Epidemiology and Public Health (2017), 2(2): 94-106

https://doi.org/10.26911/jepublichealth.2017.02.02.01

\title{
Biological, Physical, Social, and Environmental Factors Associated with Dengue Hemorrhagic Fever in Nganjuk, East Java
}

\author{
Ike Nurrochmawati',2), Ruben Dharmawan3), Pawito4) \\ 1)Diploma Program in Midwifery, STIKes Satria Bhakti, Nganjuk \\ 2)Masters Program in Public Health, Universitas Sebelas Maret \\ 3)Faculty of Medicine, Universitas Sebelas Maret \\ 4)Faculty of Social and Political Science, Universitas Sebelas Maret
}

\begin{abstract}
Background: Dengue Hemorrhagic Fever (DHF) is an infectious disease transmitted by mosquitoes that carry dengue virus (DV). This disease is endemic in more than 100 countries. Nganjuk district, East Java, is a DHF endemic area with sharp increase in DHF incidence by $286 \%$ from 2014 to 2015, of which 9 cases died. This study aimed to examine biological, physical, social, and environmental factors associated with dengue hemorrhagic fever in Nganjuk, East Java.

Subjects and Method: This study was observational analytic with case control design. It was conducted in Nganjuk District, East Java, from May to June, 2017. A sample of 120 children aged less than 15 years old were selected for this study by fixed disease sampling. This sample consisted of 40 children with DHF selected as cases and 80 neighboring children without DHF selected as controls. The independent variables were the existence of bush surrounding the house, existence of mosquito larvae, still water, hung clothes, mosquito breeding place control (PSN), and activity of larva monitoring cadre. The dependent variable was DHF cases. The data were collected by a set of pre-tested questionnaire and observation with a checklist. Logistic regression was employed for data analysis.

Results: Incidence of DHF case was determined by the existence of bush surrounding the house $(\mathrm{OR}=2.14 ; 95 \% \mathrm{CI}=0.99$ to $4.6 ; \mathrm{p}=0.052)$, existence of mosquito larvae $(\mathrm{OR}=14.94 ; 95 \% \mathrm{CI}=5.91$ to $37.73 ; \mathrm{p}<0.001)$, still water $(\mathrm{OR}=11.42 ; 95 \% \mathrm{CI}=4.68$ to $27.89 ; \mathrm{p}<0.001)$, hung clothes $(\mathrm{OR}=4.31 ; 95 \% \mathrm{CI}=1.92$ to $9.70 ; \mathrm{p}<0.001)$, mosquito breeding place control $(\mathrm{OR}=0.06 ; 95 \% \mathrm{CI}=$ 0.02 to $0.15 ; \mathrm{p}<0.001)$, and activity of larva monitoring cadre $(\mathrm{OR}=0.14 ; 95 \% \mathrm{CI}=0.06$ to 0.32 ; $\mathrm{p}<0.001)$.

Conclusion: Existence of bush surrounding the house, existence of mosquito larvae, still water, hung clothes, mosquito breeding place control, and activity of larva monitoring cadre, are the determinants of DHF incidence.
\end{abstract}

Keywords: biological, physical, social, environmental factor, mosquito breeding place control, Dengue Hemorrhagic Fever

\section{Correspondence:}

Ike Nurrochmawati. Diploma Program in Midwifery, STIKes Satria Bhakti, Nganjuk, East Java. Email: ike.nurrochma@gmail.com. Mobile: +6282141578108.

\section{BACKGROUND}

Dengue Hemorrhagic Fever (DHF) is an infectious disease transmitted by mosquetoes carrying the dengue virus. Dengue virus (DV) is the most widespread arbovirus and is endemic in more than 100 countries (Herrero et al., 2013).
Two out of five people in the world are at risk of being infected with the dengue virus and each year results in around 24,000 deaths (WHO, 2013). From 1968 to 2009, cases had spread and increased in number, from only 2 provinces and 2 cities. In 2014, among out of 100,347 dengue cases in Indonesia, 907 died (Ministry of Health, Republic of Indonesia, 2015b). At 
present the area of spread of DHF cases is increasing, reaching all provinces in Indonesia, namely 33 provinces (Ministry of Health RI, 2014).

Most cases of DHF are reported in areas with high density, such as provinces in Java, Bali and Sumatra (Ministry of Health, 2011). According to the highest number of deaths in 2014, East Java Province was the third province with the highest mortality rate of 107 deaths from 9,273 patients (Ministry of Health RI, 2015b).

Nganjuk Regency is one of 38 districts in East Java Province and is an endemic area of DHF. According to data from the Nganjuk District Health Office (2016), in 2015, the province of East Java experienced a very significant increase. In 2014, there were 120 cases and in 2015 there were 344 cases with 9 deaths.

Indicators that are used to control dengue disease are the larva free number (ABJ). In 2014, ABJ nationally had not reached the program target of $\geq 95 \%$. In 2014, ABJ in Indonesia amounted to 24.06\%. However, the validity of ABJ data above cannot be used as a definite measure because ABJ data reporting does not cover all regencies. Most puskesmas do not carry out periodic larva monitoring activities (PJB) routinely, cadres of larvae (Jumantik) also do not work in most areas due to limited budget allocations in the regions for both activities (Ministry of Health RI, 2015b).

Environmental factors are the main factors that determine the transmission of DHF. Environmental factors are biological, physical and social environments that support mosquito breeding (Sarfraz et al., 2012). Biological environmental factors are the presence of many plants in the yard and the presence of mosquito larvae (Dhillon, 2006; Brunkard et al., 2007). Physical environmental factors are the presence of a Water Shelter (TPA) and the presence of hanging clothes (Sukowinarsih and Cahyati, 2010). Social factors are the continuity of eradication of mosquito nests (PSN) DBD and activeness of jumantik cadres (AlDubai et al., 2013; Taviv et al., 2010).

Based on the results of preliminary studies, the continuity of PSN with consistent and presence of larvae in water reservoirs is a social and biological factor in Nganjuk District which affects the incidence of DHF. ABJ in Nganjuk Regency in 2015 increased to 90\% compared to 2014 which amounted to $89 \%$, but the figure still did not reach the National program target. Hanging clothes are almost all over the homes of residents in Nganjuk Regency and are physical factors of DHF incidence, because after sucking the blood of DHF patients, mosquitoes will rest in a place adjacent to the breeding habitat while waiting for the process of maturation of the eggs. Places that mosquitoes like to sit on and rest are dark and humid conditions/ places, such as hanging clothes inside the house.

Efforts to overcome the problem of dengue in Indonesia according to the Decree of the Minister of Health of the Republic of Indonesia number: 581/ MENKES/ SK/ VII/ 1992 concerning the eradication of DHF are carried out appropriately by the government cooperating with the community which includes: (1) prevention, (2) discovery, help and reporting, (3) epidemiological investigations and observations of dengue hemorrhagic fever, (4) countermeasures as needed, (5) other countermeasures and (6) counseling. The implementation of DHF eradication activities is carried out by the government and the community under the coordination of the Head of Region / Region (Ministry of Health RI, 2011). 
Journal of Epidemiology and Public Health (2017), 2(2): 94-106

https://doi.org/10.26911/jepublichealth.2017.02.02.01

The researchers examined the biological, physical and social environmental factors that influence the incidence of DHF in Nganjuk District, East Java Province. The purpose of this study is to explain the effect of biological, physical and social environmental factors that influence the incidence of DHF in Nganjuk Regency.

\section{SUBJECTS AND METHOD \\ 1. Study Design \\ This study uses observational analytic studies with a case control study approach. Factors to be studied are the presence of plants, the presence of mosquito larvae, the presence of landfill, the presence of hanging clothes, the continuity of dengue PSN and the activeness of cadres who will be seen to influence the incidence of dengue in Nganjuk District. The data collection was carried out with observation sheets filled by jumantik cadres in the research subject area. The data processing was carried out using a multiple logistic regression.}

\section{Population and Samples}

The study was conducted from May to June 2017. The study population was all residents in Nganjuk Regency. The sample used in multivariate study is a minimum of 5: 1 ratio and it is recommended to use 15 to 20 subjects for each independent variable. The number of independent variables in this study was six variables, so the number of the study subjects between 90 to 120 . The ratio of the number of case control was $1: 2$, so that the case is 40 people and the control is 80 people (Hair et al, 1998 cited by Murti, 2013).

\section{Sampling Technique}

The sampling in this study was determined by fixed disease sampling, which was to ensure that the number of study subjects was sufficient in diseased (case) and nondiseased (control) groups, thus benefiting researchers when the prevalence of the disease under study was low (Gerstman, 1998 cited by Murti, 2013).

The sample of this study is a part of the population in two sub-districts with the highest DHF cases in Nganjuk Regency and is an endemic sub-district in Nganjuk Subdistrict and Loceret District. The study sample consisted of case samples and control samples. Cases are children aged less than 15 years in Nganjuk District who were hospitalized in the period October 2016 to March 2017 and diagnosed with DHF / DD / DSS. Controls are neighboring cases who have never been hospitalized at the same time as restricted inclusion and exclusion criteria.

\section{Study Variables}

The dependent variable was DHF. The independent variables werebpresence of plants, the presence of mosquito larvae, the presence of water reservoirs (TPA), the presence of hanging clothes, the continuity of eradication of mosquito nests (PSN) DBD and the active cadres of larvae monitors.

\section{Operational Definitions}

The existence of plants was defined as the finding of many plants in the research subject house which affect the lighting and humidity around the house as measured by the observation sheets. The measurement scale was categorical, coded $\mathrm{o}=$ plant $<14$ in home yard and $1=$ found plant $\geq 14$.

The existence of mosquito larvae was defined as a condition where mosquito larvae are found either inside the house or outdoors in a water reservoir (TPA) such as bathtub/ toilet, drums/ barrel/ crock, refrigerator/ dispenser, cans / used tires around the house etc. which are measured by observation sheets. The measurement scale is categorical, with parameter $\mathrm{o}=$ no larvae are found and $1=$ there are larvae found at least one wiggler. 
The existence of a water shelter was defined as a condition in which a water reservoir is found either inside the house or outside the home in an open condition that has the potential to become a place for mosquito breeding as measured by the observation sheets. The measurement scale was categorical, coded o for no landfill that has the potential to be a place for mosquitoes to breed and 1 for potential landfill for mosquitoes to breed.

The existence of hanging clothes was defined as a condition in which clothes that have been worn are found hanging inside the house as measured by the observation sheet. The measurement scale was categorical, coded o for none and 1 for yes.

Continuity of Eradication of Mosquito Nests (PSN) DHF is defined as an activity carried out by research subjects sonce a week to eradicate mosquito nests in places that allow mosquitoes to lay eggs, in the form of $3 \mathrm{M}$ plus. The measurement scale was continuous, but for the data analysis it was transformed into dichotomy, coded o for poor and 1 for good.

Jumantik cadre activeness was defined as a condition in which every one week a research subject found that special officers came from the surrounding environment of the study subject who volunteered to be responsible for monitoring Aedes aegypti mosquito larvae and reporting to the village. The measurement scale was categorical, coded o for not active and 1 for active.

DHF case were defined as children under 15 years old in Nganjuk District who suffer from DHF and were hospitalized in October 2016 to March 2017. The measurement scale was categorical, coded o for no and 1 for yes.

\section{Research Ethics}

Researchers pay attention to the research ethics, namely by providing informed consent which is the consent sheet given to the research subject in order to find out the research intent, anonymity which is not mentioning the name of the research subject, confidentiality which is maintaining the confidentiality of information provided by the research subjects.

\section{Data Processing}

The data processing is done by editing techniques, namely checking the instrument that has been filled in, scoring that is giving the value of each question item and adding it up, coding data is giving the research data code for statistical analysis, data entry is entering data from the questionnaire into computer data according to statistical data, tabulating is processing data by aiming to create a table that can provide a statistical description.

\section{Data Analysis}

The data analysis techniques include bivariate analysis which aims to analyze the relationship of two variables using the chisquare test with a $2 \times 2$ contingency table to find out how much influence is one independent to the dependent one. Multivariate analysis of multiple logistic regression aims to measure the influence of more than one independent variable on the dependent variable.

\footnotetext{
RESULTS

Based on Table 1, the number of the study subjects was 120 children under 15 years old. The study subjects were 40 people who had been diagnosed with DHF / DD as a case group and 80 people were neighbors of patients (case group) who had never suffered from DHF as a control group. The study subjects were from 16 villages in Nganjuk Subdistrict and Loceret Subdistrict. The most subjects who were diagnosed with DHF coming from Ngepeh Village by $15 \%$.
} 
Journal of Epidemiology and Public Health (2017), 2(2): 94-106

https://doi.org/10.26911/jepublichealth.2017.02.02.01

Table 1. Characteristics of the Study Subjects

\begin{tabular}{lcccc}
\hline \multicolumn{1}{c}{ Address } & \multicolumn{2}{c}{ DHF } & \multicolumn{2}{c}{ Non-DHF } \\
\cline { 2 - 5 } & $\mathbf{n}$ & $\mathbf{\%}$ & $\mathbf{1 2}$ & $\mathbf{\%}$ \\
\hline Desa Ngepeh & 6 & 15 & 10 & 15 \\
Desa Putukrejo & 5 & 12.5 & 10 & 12.5 \\
Desa Nglaban & 5 & 12.5 & 4 & 5 \\
Desa Bajulan & 2 & 5 & 4 & 5 \\
Desa Genjeng & 2 & 5 & 4 & 5 \\
Desa Macanan & 2 & 5 & 2 & 2.5 \\
Desa Patihan & 1 & 2.5 & 2 & 2.5 \\
Desa Gejagan & 1 & 2.5 & 2 & 2.5 \\
Desa Tanjungrejo & 1 & 2.5 & 2 & 2.5 \\
Desa Sukorejo & 1 & 2.5 & 4 & 12.5 \\
Kel. Ploso & 5 & 12.5 & 4 & 5 \\
Kel. Begadung & 2 & 5 & 2 & 5 \\
Kel. Mangundikaran & 2 & 5 & 2 & 2.5 \\
Kel. Kauman & 1 & 2.5 & 6 & 2.5 \\
Kel. Balongpacul & 1 & 2.5 & 80 & 7.5 \\
Kel. Kartoharjo & 3 & 7.5 & 100 \\
Total & 40 & 100 & &
\end{tabular}

Table 2 shows the bivariate results data about the effect of one independent variable on the dependent variable. The independent variables of this study were the presence of plants, the presence of mosquito larvae, the presence of water reservoirs, the presence of hanging clothes, the continuity of eradication of DHF mosquito nests and the active cadres of larvae observers. The dependent variable of this study is the case of DHF.

Table 2. The Characteristics of continuous data studies and controls

\begin{tabular}{lcccc}
\hline & \multicolumn{4}{c}{ DHF Case } \\
\cline { 2 - 5 } \multicolumn{1}{c}{ Variables } & \multicolumn{2}{c}{ Case (n=40) } & \multicolumn{2}{c}{ Control (n=80) } \\
\cline { 2 - 5 } & $\mathbf{n}$ & $\mathbf{\%}$ & $\mathbf{N}$ & $\mathbf{\%}$ \\
\hline The existence of plants & 16 & 40 & 49 & 61 \\
Not found & 24 & 60 & 31 & 39 \\
$\begin{array}{l}\text { Found } \\
\text { The existence of mosquito larvae }\end{array}$ & 11 & 27 & 68 & 85 \\
Not found & 29 & 73 & 12 & 15 \\
Found & & & & \\
The existence of a landfill & 11 & 27 & 65 & 81 \\
Not found & 29 & 73 & 15 & 19 \\
Found & & & & \\
The existence of hanging clothes & 13 & 33 & 54 & 67 \\
Not found & 27 & 67 & 26 & 33 \\
Found & & & & \\
Continuity of DHF PSN & 31 & 78 & 13 & 16 \\
Poor & 9 & 22 & 67 & 84 \\
Good & & & & \\
The activeness of Jumantik cadres & 25 & 63 & 15 & 19 \\
Inactive & 15 & 37 & 65 & 81 \\
Active & & &
\end{tabular}


Based on Table 2, it can be seen that the presence of plants in the control group for about 61 subjects (61\%) found no plant in the yard. Different results were shown by the case group for about 24 subjects (60\%) found the presence of plants in the yard of the house. In the presence of larvae about 68 subjects $(85 \%)$, there were no more mosquito larvae than the case group. Likewise, the variables of the presence of landfill for about 65 subjects in the control group (81\%) were more often not found in the landfill which has the potential to become mosquito breeding sites compared to the case group.

The variables of the presence of more hanging clothes were not found in the control group subjects which were 56 subjects (67\%) compared to the case group. In the continuity of DHF mosquito nests eradication, most of the control group subjects were in eradication of DHF mosquito nests continuity, which were 67 subjects (84\%). While the variables of activeness of jumantik cadres for about 65 subjects (81\%) in the control group contained active jumantik cadres.

Table 3 on the variable of plant existence showed the score of Odds Ratio value on the variable by 2.14 , meaning that a house with more than 14 trees in the yard has 2.14 times greater chance of suffering from DHF. The results of analysis showed that there was a relationship between the existence of plants on the incidence of DHF which was statistically nearly significant $(\mathrm{OR}=2.14$; CI 95\%= 0.99 to $4.6 ; \mathrm{p}=0.052)$.

The variable of the existence of mosquito larvae showed the Odds Ratio score on the variable by 14.94 , meaning that if the mosquito larvae was found in the residence environment, it has 14.94 times greater chance of suffering from DHF. The results of analysis showed that there was a relationship between the existence of the mosquito larvae and the incidence of DHF which was statistically significant (OR= 14.94; CI $95 \%=5.91$ to $37.73 ; \mathrm{p}<0.001)$.

The existence of water reservoirs variable showed the Odds Ratio score on the variable by 11.42, this mean that if an opened water reservoir was found in a home environment, then it has the potential to become a mosquitoes breeding place, and people who lived in such place were $\mathbf{1 1 . 4 2}$ times more likely to have DHF. The results of analysis showed that there was a relationship between the existence of water reservoirs on the incidence of $\mathrm{DHF}$ which was statistically significant $(\mathrm{OR}=$ 11.42; $95 \% \mathrm{CI}=4.68$ to $27.89 ; \mathrm{p}<0.001)$.

The existence of hanging clothes variable showed the Odds Ratio score on the variable by 4.31 , meaning that if the hanging clothes which have been used were found inside the house, people who lived in that house were 4.31 times more likely to be infected by DHF. The results of analysis showed that there was a relationship between the existence of hanging clothes on the incidence of DHF which was statistically significant $(\mathrm{OR}=4.31 ; 95 \% \mathrm{CI}=1.92$ to $9.70 ; \mathrm{p}<0.001)$.

The continuity of DHF PSN variable showed the Odds Ratio score on the variable by 0.06 , meaning that the residences that did not do DHF PSN activities would continuously have a likelihood by 0.06 times to have DHF. The results of analysis showed that there was a relationship between the continuity of DHF PSN on the incidence of DHF which was statistically significant $(\mathrm{OR}=0.06 ; \mathrm{CI}$ $95 \%=0.02$ to $0.15 ; \mathrm{p}<0.001)$.

The activeness of larvae monitoring cadre variable showed the score of Odds Ratio on the variable by 0.14 , meaning that people who lived in the house that was not monitored by larvae monitors once a week was 0.14 times more likely to suffer from 
Journal of Epidemiology and Public Health (2017), 2(2): 94-106

https://doi.org/10.26911/jepublichealth.2017.02.02.01

DHF. The results of analysis showed that there was a relationship between the activeness of larvae monitoring cadre on the incidence of DHF which was statistically significant $(\mathrm{OR}=0.14$; $\mathrm{CI} 95 \%=0.06$ to $0.32 ; \mathrm{p}<0.001)$.

Table 3. Bivariate Analysis of the Existence of Plants, Mosquito Larvae, Water Reservoirs, Hanging Clothes, the Continuity of DHF PSN, and the Activeness of Larvae Monitoring Cadre on the Incidence of DHF

\begin{tabular}{|c|c|c|c|c|c|c|c|c|}
\hline \multirow{3}{*}{ Variable } & \multicolumn{4}{|c|}{ DHF Incident } & \multirow{3}{*}{$\mathbf{O R}$} & \multirow{2}{*}{\multicolumn{2}{|c|}{ 95\% CI }} & \multirow{3}{*}{$\mathbf{p}$} \\
\hline & \multicolumn{2}{|c|}{ Cases } & \multicolumn{2}{|c|}{ Control } & & & & \\
\hline & $\mathbf{n}$ & $\%$ & $\mathbf{n}$ & $\%$ & & $\begin{array}{l}\text { Lower } \\
\text { Limit }\end{array}$ & $\begin{array}{l}\text { Upper } \\
\text { Limit }\end{array}$ & \\
\hline The Existence of Plants & & & & & & & & \\
\hline Not Found & 16 & 25.8 & 49 & 74.2 & 2.14 & 0.99 & 4.6 & 0.052 \\
\hline Found & 24 & 42.6 & 31 & 57.4 & & & & \\
\hline The Existence of Mosquito & & & & & & & & \\
\hline $\begin{array}{l}\text { Larvae } \\
\text { No Larvae Found }\end{array}$ & 11 & 13.9 & 68 & 86.1 & 14.94 & 5.91 & 37.73 & $<0.001$ \\
\hline Found & 29 & 70.7 & 12 & 29.3 & & & & \\
\hline The Existence of Water & & & & & & & & \\
\hline $\begin{array}{l}\text { Reservoirs } \\
\text { Not Found }\end{array}$ & 11 & 14.5 & 65 & 85.5 & 11.42 & 4.68 & 27.89 & $<0.001$ \\
\hline Found & 29 & 65.9 & 15 & 34.1 & & & & \\
\hline The Existence of Hanging & & & & & & & & \\
\hline $\begin{array}{l}\text { Clothes } \\
\text { Not Found }\end{array}$ & 13 & 19.4 & 54 & 80.6 & $4 \cdot 31$ & 1.92 & 9.70 & $<0.001$ \\
\hline Found & 27 & 50.9 & 26 & 49.1 & & & & \\
\hline $\begin{array}{l}\text { The Continuity of DHF } \\
\text { eradication nest }\end{array}$ & & & & & 0.06 & & 0.15 & $<0.001$ \\
\hline Poor & 31 & 70.5 & 13 & 29.5 & 0.00 & 0.02 & 0.15 & \\
\hline Good & 9 & 11.8 & 67 & 88.2 & & & & \\
\hline $\begin{array}{l}\text { The Activeness of Larvae } \\
\text { Monitoring Cadre }\end{array}$ & & & & & & & & \\
\hline Not Active & 25 & 62.5 & 15 & 37.5 & 0.14 & 0.06 & 0.32 & $<0.001$ \\
\hline Active & 15 & 18.8 & 65 & 81.2 & & & & \\
\hline
\end{tabular}

The results of multivariate analysis between the independent variables on the dependent variable with the logistic regression test in table 4 showed that the independent variable which became the factor in increasing the incidence of DHF was the existence of plants $(\mathrm{OR}=3.31 ; 95 \%$ $\mathrm{CI}=0.90$ to $12.20 ; \mathrm{p}=0.071$ ) even though it was statistically nearly significant.

Table 4. The Multivariate Analysis Results of Multiple Logistic Regression

\begin{tabular}{|c|c|c|c|c|}
\hline \multirow{2}{*}{ Variable } & \multirow{2}{*}{$\mathbf{O R}$} & \multicolumn{2}{|c|}{ CI 95\% } & \multirow{2}{*}{$\mathbf{p}$} \\
\hline & & Lower Limit & Upper Limit & \\
\hline The Existence of Plants & $3 \cdot 31$ & 0.90 & 12.20 & 0.071 \\
\hline The Existence of Mosquito Larvae & 7.74 & 2.13 & 28.14 & 0.002 \\
\hline The Existence of Water Reservoirs & 6.44 & 1.57 & 26.45 & 0.010 \\
\hline The Existence of Hanging Clothes & 5.08 & 1.35 & 19.05 & 0.016 \\
\hline The Continuity of DHF PSN & 0.18 & 0.05 & 0.68 & 0.012 \\
\hline The Activeness of Larvae Monitoring Cadre & 0.19 & 0.05 & 0.66 & 0.009 \\
\hline N Observation & 120 & & & \\
\hline-2 log likelihood & 67.67 & & & \\
\hline Nagelkerke $\mathrm{R}^{2}$ & $70.5 \%$ & & & \\
\hline
\end{tabular}


The existence of mosquito larvae variable $(\mathrm{OR}=7.74 ; 95 \% \mathrm{CI}=2.13$ to 28.14 ; $\mathrm{p}=0.002)$, the existence of water reservoirs $(\mathrm{OR}=6.44 ; 95 \% \mathrm{CI}=1.57$ to $26.45 ; \mathrm{p}=$ o.010), the existence of hanging clothes $(\mathrm{OR}=5.08 ; 95 \% \mathrm{CI}=1.35$ to $19.05 ; \mathrm{p}=$ o.016) also increase the incidence of DHF and it was statistically significant. The continuity of DHF PSN (OR=0.18; 95\% $\mathrm{CI}=0.05$ to $0.68 ; \mathrm{p}=0.012)$ and the activeness of larvae monitoring cadre $(\mathrm{OR}=$ $0.19 ; 95 \% \mathrm{CI}=0.05$ to $0.66 ; \mathrm{p}=0.009$ ) decrease the incidence of DHF which was statistically significant.

The existence of plants $(\mathrm{OR}=3.31)$, mosquito larvae $(\mathrm{OR}=7.74)$, water reservoirs $(\mathrm{OR}=6.44)$ and hanging clothes variables $(\mathrm{OR}=5.08)$ were the risk factors of DHF incident. The continuity of dengue eradication nest $(\mathrm{OR}=0.18)$ and the activeness of larvae monitoring cadre variables $(\mathrm{OR}=0.19)$ were the protective factors for the occurence of DHF or in other words, they were the variables that can reduce the incidence of DHF.

\section{DISCUSSIONS}

\section{The Effect of the Existence of Plants on DHF}

The result of analysis showed that there was an effect of the existence of plants on the incidence of DHF which was statistically close to significant based on the results of the bivariate test. This illustrated that most of DHF sufferers have plants on the yard, there were 24 subjects (6o\%) out of 40 subjects.

The result of this study supported a study conducted in Vietnam in 2008 by Phuong et al. (2008) which stated that from the five variables, the presence of numerous plants near the house was the factor that affect the incidence of DHF (RR 2,22; 95\% CI 1,18-4,17). In addition, a study by Winarsih (2011) in Semarang stated that there was a relationship between the existence of plants and the incidence of DHF.

This was in accordance with a theory of Soegijanto (2003), which stated that the number of plants around the house affected the humidity and lighting of the house and it was a favorite place for the mosquito to perch and breed. Therefore, the number of plants in the yard would provide the places for mosquito to perch and increase the age of the mosquito (Dhillon, 2008).

From the descriptions above, it can be concluded that people who have many plants in their yard were more likely to be affected by DHF than those who lived in the environment with few plants in the yard. According to Brigit et al., (2004) quoted by Wahyono et al., (2010), if the number of plants in the yard were $\geq 14$ trees, then the people who lived in that place were more likely to be affected by DHF.

\section{The Effect of the Existence of Mosquito Larvae on DHF}

The result of analysis showed that there was an effect of the existence of mosquito larvae on the incidence of DHF and it was statistically significant based on bivariate and multivariate tests. The results showed that people who live in an environment which has mosquito larvae were more likely to have DHF.

This study was in line with a study by Sunaryo \& Pramestuti (2014) in four DHF endemic districts/cities in Central Java, namely Grobogan, Purbalingga, Kendal, and Semarang, which showed the results that DHF cases raising in the four districts/cities were affected by the agent, which was the Aedes Aegypti mosquito vector. The increase in the number of water reservoirs which contaminated by larvae affected the enhancement of DHF cases (Sunaryo and Pramestuti, 2014). 
Journal of Epidemiology and Public Health (2017), 2(2): 94-106

https://doi.org/10.26911/jepublichealth.2017.02.02.01

The presence of living mosquito larvae would lead to the incidence of DHF. Mosquito larvae can live and breed in various places such as water reservoirs for daily needs both inside and outside the house, including bucket, drum, bathtub/ toilet, etc. Water reservoirs were not for daily needs, including bird drinking places, flower vases, ant traps, used items, gutters, and others. Also on natural water reservoirs, such as tree holes, stone holes, leaf midribs, coconut shells, bamboo pieces, banana midribs, and others (Ministry of Health RI, 2013).

After 6-8 days, it became a larva, and developed into a cocoon and after 2 days, it turned to an adult mosquito (the breeding of egg-larvae-cocoon-mosquito took 7-10 days). If the mosquito larvae was ignored, then the incidence of DHF would be increased. Therefore, the presence of mosquito larvae in the water reservoirs both inside and outside the house must be controlled. Because the right control of DHF was by breaking the transmission chain, which was by controlling the vector (Brunkard et al., 2007).

\section{The Effect of Water Reservoirs on DHF}

The result of analysis showed that there was an effect of the existence of water reservoirs on the incidence of DHF and it was statistically significant on bivariate and multivariate tests. This illustrated that the presence of the opened water reservoirs in the home environment has the potential to become a place for mosquitoes to breed, and it affected the incidence of DHF. Water reservoir was a medium for Aedes Aegypti mosquitoes to breed, because mosquitoes placed their eggs on the water reservoirs. In order to avoid the Aedes Aegypti mosquitoes from laying their eggs on the water reservoirs, people should drain the water reservoirs once a week or close the water reservoirs which were used for daily needs. Therefore, the mosquito eggs cannot grow into adult mosquitoes that were ready to transmit the DHF (Health Department, 2005).

This study supported a study by Sukowinarsih and Cahyati in Semarang, which stated that the presence of larvae in water reservoirs can affect the incidence of DHF by 3.38 times (Sukowinarsih and Cahyati, 2010). In addition, a study by Wahyono, et.al (2010) stated that statistically, there was a significant relationship between the existence of water reservoirs and the incidence of DHF.

This was in accordance with the theory which stated that the presence of water reservoirs could give great contribution for the increase of Aedes Aegypti mosquitoe larvae which correlated to the incidence of DHF (Soeroso, 2000). The presence of water reservoirs was very important in the density of Aedes Aegypti mosquitoes vector, because the more the water reservoirs, the more the breeding places, and the population of Aedes Aegypti mosquitoes would become more dense (Dash et al., 2012).

\section{The Effect of the Existence of Hanging Clothes on DHF}

The results of statistical tests both bivariate and multivariate showed that there was a significant effect of the existence of hanging clothes on the incidence of DHF. It showed that the existence of hanging clothes in the house affected the incidence of DHF. This mean that subjects who lived in the house with hanging clothes were more likely to suffer from DHF than those who did not have hanging clothes inside their houses.

The result of this study was in accordance with Triad epidemiology theory which explained that the occurrence of illness was caused by three components, namely host, agent, and environment 
factors. The effect of the existence of hanging clothes was part of the environmental factors which in triad epidemiology can lead to the occurrence of diseases such as DHF.

This study supported a study by Sukowinarsih and Cahyati (2010) in Semarang, which stated that people who have hanging clothes inside their house were 4.405 times more likely to have DHF. In addition, the result of a study by Dinata and Dhewantara (2012) stated that the existence of hanging clothes affected the incidence of DHF by $80 \%$ in endemic areas. This was in line with a study done by Widyana (1998), which showed that the habit of hanging clothes affected the incidence of DHF in Bantul Regency.

Aedes Aegypti mosquitoes rest on the clothes that have been worn which hanging on the room, because in some clothes, there were some substances that can attract the mosquitoes such as amino acids, lactic acid, and other substances. Mosquitoes were attracted to the scent of the human body because the carbon dioxide from breathing was attached to their clothes. Furthermore, if the clothes were hung, it would increase the population of mosquitoes that live in the house (Soetaryo, 2004). Supposedly, the clothes should be folded and stored in the closets, because the Aedes Aegypti mosquitos liked to perch and rest in a dark place and in hanging clothes (Yatim, 2007).

\section{The Effect of the Continuity of Dengue Eradication Nest on DHF}

The result of this study showed that there was an effect between the continuity of DHF PSN and the incidence of DHF and it was statistically significant for both bivariate and multivariate tests. This illustrated that the continuity of eradication of mosquito nests affected the incidence of DHF. People who lived in the houses that continuously eradicate the mosquito nests were less likely get infected by DHF.

Mosquito nests eradication was an effort to control and prevent DHF disease with $3 \mathrm{M}$ plus action, which was accompanied by continuous monitoring. DHF PSN action was the most important part of the overall effort to eradicate DHF. The implementation of PSN should be carried out continuously along with larvae examination at least once a week to break the chain of transmission. If the Aedes Aegypti mosquito vector can be controlled, the population of Aedes Aegypti mosquitoes can be reduced as low as possible. Therefore, the transmission of DHF did not occur (Ministry of Health RI, 2011).

Indonesia is one of the endemic countries of dengue fever, and the outbreaks $(\mathrm{KLB})$ were always happened in every year in various cities, and every 5 years there was a large outbreak. DHF outbreak can be avoided if the Early Warning Alert and Response System (EWARS) and vector control were good, integrated, and sustainable. Vector control through vector surveillance was regulated in the Decree of the Ministry of Health No.581 of 1992, which stated that mosquito nest eradication (PSN) activities were carried out periodically by the community coordinated by CG/NG in the form of PSN with $3 \mathrm{M}$ plus core messages. The success of PSN activities can be measured, among other things, by the Larvae Free Index (LFI). If the LFI was more than or equal to $95 \%$, it was expected that DHF transmission can be prevented or reduced (Central Data and Epidemiological Surveillance of the Ministry of Health RI, 2010).

The approach of community participation action must be fostered and organized because it involved many parties and needed one system through the working group (POKJANAL) so that it could be 
Journal of Epidemiology and Public Health (2017), 2(2): 94-106

https://doi.org/10.26911/jepublichealth.2017.02.02.01

more optimal. POKJANAL was an operational working group which the membership consisted of various elements of service/government agencies, NGO, private or business world that functionally have the task of increasing community participation in DHF PSN (Ministry of Health RI, 2011).

This study was in line with a study done by Al-Dubai et al., (2013) which stated that the practice of mosquito nests eradication affected the incidence of DHF in Malaysia. Furthermore, a study by Ananda and Hidayatullah (2015) showed that PSN was positively correlated with the presence of larvae, and the presence of larvae can be reduced to minimize the incidence of DHF.

\section{The Effect of the Activeness of Larvae Monitoring Cadre on DHF}

The results of statistical tests for both bivariate and multivariate showed that there was a significant effect between the activeness of larvae monitoring cadres and the incidence of DHF. This illustrated that the activeness of larvae monitoring cadres affected the incidence of DHF. People who lived the environments with active cadres in monitoring the larvae of Aedes Aegypti mosquitoes in their area were less likely to be affected by DHF.

The result of this study was in line with a study by Pratamawati (2012), which stated that the role of larvae monitoring cadres was highly important in early warning alert of DHF because it served to monitor the presence and inhibit the early development of DHF transmission vector. The activeness of larvae monitoring cadres in monitoring their environment was an important step to prevent the increasing number of DHF cases. Therefore, the efforts were needed to improve the activeness of larvae monitoring cadres through motivation provided by the local health office.
Larvae monitoring cadres were very instrumental in mobilizing community participation in eradicating the DHF. Periodic Larvae Monitoring (PLM) by larvae monitoring cadres was one of the steps to prevent the spread of DHF which was considered quite significant, especially in eradicating infectious mosquito larvae so that the transmission of DHF at the village level can be prevented or restricted (Ministry of Health RI, 2011). Therefore, the Minister of Health RI in the Minister of Health Circular number 591 of 2016 concerning The Implementation of " $3 \mathrm{M}$ Plus Mosquito Nest Eradication" with "One House, One Larvae Monitoring Cadre" Actions urged the " $3 \mathrm{M}$ plus action" and "One House, One Larvae Monitoring Cadre" to be implemented.

From the results of this study, it can be concluded that the incidence of DHF was affected by the existence of plants, mosquito larvae, water reservoirs, hanging clothes, the continuity of DHF PSN, and larvae monitoring cadre.

\section{REFERENCES}

Al-Dubai SA, Ganasegeran K, Rahman MA, Alshagga MA, Saif-Ali R (2013). Factors affecting dengue fever knowledge, attitudes and practices among selected urban, semi-urban and rural communities in Malaysia. Southeast Asian J Trop Med Public Health, 44(1): 37-49.

Ananda AF, Hidayatullah MT (2015). Pemberantasan Sarang Nyamuk Berkorelasi Positif dengan Keberadaan Jentik di Kelurahan Bintaro Kota Mataram. Jurnal Sangkareang Mataram, 1(1).

Brunkard JM, Lopez JLR, Ramirez J, Cifuentes E, Rothenberg SJ, Hunsperger EA, Moore CG, Brussolo RM, Villarreal NA, Haddad BM (2004). 
Dengue Fever Seroprevalence and Risk Factors, Texas-Mexico Border 2004. Emerging Infectious Diseases, 13(10): 1477-1483.

Dash AP, Bhatia R, Kalra NL (2012). Dengue in South-East Asia: an appraisal of case management and vector control. Dengue Bull, 36: 1-13.

Depkes RI (2005). Pencegahan dan Pemberantasan Demam Berdarah Dengue di Indonesia. Jakarta: Dirjen PP dan PL.

Dhillon GPS (2008). Guidelines for clinical management of dengue fever, Dengue hemorrhagic fever and Dengue shock syndrome. Directorate of NVBDCP, New Delhi, 14.

Dinata A, Dhewantara PW (2012). Karakteristik lingkungan fisik, biologi, dan sosial di daerah endemis DBD Kota Banjar tahun 2011. Jurnal Ekologi Kesehatan, 11(4): 315-326.

Herrero LJ, Zakhary A, Gahan ME, Nelson MA, Herring BL, Hapel AJ, Keller PA, Obeysekera M, Chen W, Sheng KC, Taylor A (2013). Dengue virus therapeutic intervention strategies based on viral, vector and host factors involved in disease pathogenesis. Pharmacology \& Therapeutics, 137(2): 266282.

Kemenkes RI (2013). Buku Saku Pengendalian Demam Berdarah Dengue untuk Pengelola Program DBD Puskesmas. Jakarta: Kemenkes RI.

(2011). Modul Pengendalian Demam Berdarah Dengue Dirjen P2PL Kementerian Kesehatan RI. (2014). Profil Kesehatan Indonesia Tahun 2013. Jakarta: Kemenkes RI. (2015). Profil Kesehatan Indonesia Tahun 2014. Jakarta: Kementerian Kesehatan RI.

Phuong HL, De Vries PJ, Boonshuyar C, Binh TQ, Nam NV, Kager PA (2008). Dengue risk factors and community participation in binh thuan province, vietnam, a household survey. Southeast Asian J. Trop. Med. Public Health, 39(1): 79-89.

Pratamawati DA (2012). Peran Juru Pantau Jentik dalam Sistem Kewaspadaan Dini Demam Berdarah Dengue di Indonesia. Jurnal Kesehatan Masyarakat Nasional, 6(6).

Sarfraz MS, Tripathi NK, Tipdecho T, Thongbu T, Kerdthong P, Souris M (2012). Analyzing the spatio-temporal relationship between dengue vector larval density and land-use using factor analysis and spatial ring mapping. BMC Public Health, 12(1): 1.

Soegijanto S (2003). Demam Berdarah Dengue: Tinjauan dan Temuan Baru di Era 2003. Surabaya: Airlangga University Press.

Soetaryo (2004). Dengue. Yogyakarta: Medika Fakultas Kedokteran UGM.

Sukowinarsih TE, Cahyati WH (2010). Hubungan Sanitasi Rumah Dengan Angka Bebas Jentik Aedes Aegypti. Jurnal Kesehatan Masyarakat, 6(1): 30-35.

Sunaryo, Pramestuti N (2014). Surveilans Aedes aegypti di Daerah Endemis Demam Berdarah Dengue. Jurnal Kesehatan Masyarakat Nasional, 8(8): 423-429.

Taviv Y, Saikhu A, Sitorus H (2010). Pengendalian DBD Melalui Pemanfaatan Pemantau Jentik Dan Ikan $\mathrm{Cu}-$ pang Di Kota Palembang. Bulletin Penelitian Kesehatan, 38(4): 215-224.

Wahyono TYM, Haryanto B, Mulyono S, Adiwibowo A (2010). Faktor-faktor yang berhubungan dengan kejadian DBD dan upaya penanggulangannya di Kecamatan Cimanngis, Depok, Jawa Barat. Buletin Jendela Epidemiologi. 
Journal of Epidemiology and Public Health (2017), 2(2): 94-106

https://doi.org/10.26911/jepublichealth.2017.02.02.01

WHO (2013). Dengue and severe dengue [factsheet no. 117, revised January 2012]. Available: Accessed, 2.

Widyana (1998). Faktor-Faktor yang Mempengaruhi Kejadian DBD Di Kabupaten Bantul. Jurnal Epidemiologi Indonesia. 2(7): 1-1988
Winarsih S (2013). Hubungan kondisi lingkungan rumah dengan perilaku PSN DBD dengan kejadian DBD. Unnes Journal of Public Health.

Yatim F (2007). Macam-Macam Penyakit Menular dan Cara Pencegahannya Jilid 2. Jakarta: Pustaka Obor Populer 